\title{
An analysis of the feminist-figurational debate on the study of gender and sport
}

\author{
Maria Claudia Pinheiro*
}

\begin{abstract}
This article provides an analysis of the debate that has been taken place about the possibility of blending figurational and feminist perspectives on the study of gender and sport. In this analysis, some of the differences between feminist and figurational approaches are briefly mentioned and Elias's ideas on involvement and detachment are presented as a possible solution to combine figurational and feminist approaches.
\end{abstract}

Keywords: sociology; feminism; gender identity; sports.

\section{INTRODUCTION}

With the consolidation of feminist theories, gender and sport issues have been highly discussed, over the last decades. Some theories, such as liberal feminism focus on the women's lack of access and opportunities to sports settings and on the "socialization and sex-role differentiation" (SCRATON; FLINTOFF, 2002a, p. 33) to explain women's under-representation in sport. Radical feminism tends to focus on male control of sports practices and governing bodies. They concentrate their attention on the role sport plays in "the social construction of male sexual dominance and female sexual submission" (SCRATON; FLINTOFF, 2002a, p. 35). In the sports context, radical feminists believe that sport helps to encourage women to develop "an acceptable femininity" (SCRATON; FLINTOFF, 2002a, p. 35). Socialism feminism focuses on the sexual

\footnotetext{
*Departamento de Educação Física e Desporto. Instituto Superior da Maia. Centro de Estudos em Educação, Tecnologias e Saúde (Cl\&DETS). Maia, Portugal. E-mail: pinclaudia@gmail. com
} 
division of labour within sport in order to explain women's lower representation in sport when compared to men. Poststructuralist feminism, have been trying to "challenge current and popular ways of dichotomous thinking about femininity/masculinity, heterosexuality/ homosexuality, black/white ... because people negotiate multiple identities" (LISTON, 2007, p. 625). It can be said, that feminists, in a general way, have been focusing, on the reproduction, within the sports context, of unequal power relations between males and females, on the experiences of females in sport, on what this means to men and how it may benefit them and also the consequences for females self-images (LISTON, 2007).

The various feminist approaches have been developing different questions and explanations in relation to women's involvement in sport that have to be considered of great importance. Indeed, the contribution of several feminist scholars (BIRRELL, 2000; CAUDWELL, 1999; HARGREAVES, 1994; MARKULA, 1995, 2003; SCRATON; FLINTOFF, 2002b; THEBERGE, 2003) to a better understanding of women in sport and more precisely of gender and sport cannot be denied. However, the way feminist scholars refer to gender and sport do present some problems.

Drawing on several studies about women's sports this paper attempts to point out what we take to be the main tensions between figurational and feminist approaches. The arguments of some authors who consider to be difficult to combine both perspectives and the points of view of others who believe it is possible to be a feminist figurational sociologist are discussed. In this context, Elias's ideas on involvement-detachment are presented as a possible solution to blend figurational and feminist approaches.

\section{Figurational SOCIOLOGY VERSUS FEMINIST SOCIOLOGY}

Figurational sociology has been criticised by feminist sociologists such as Hargreaves for its "gender blindness". However, while Dunning (1992a, p. 255) has recognised that in the past figurational sociologists have "been too silent on questions

Movimento, Porto Alegre, v. 20, n. 2, p. 757-773, abr.jun. de 2014. 
of gender", this does not mean that they have altogether ignored gender issues. In fact, not only Elias, but also other figurational sociologists, have addressed issues of gender relations and sport (COLWELL, 1999; DUNNING, 1992b; DUNNING; SHEARD, 1979; MAGUIRE; MANSFIELD, 1998; WADDINGTON; MALCOLM; COBB, 1998).

It is suggested that figurational sociology does offer a useful analysis of gender relations and the nature of gender/power relations within sport. In fact, sport and gender problems are, according to Dunning (1999), better understood by reference to the theory of the civilizing process. This theory attempts to trace different trajectories of development in western societies, especially Britain, Germany and France from the Middle Ages to the early twentieth century. Since most of what has been written about gender and sport has focused on eastern societies and especially Britain, most of what will be discussed in the present article, refers to English society which is often considered as the birthplace of modern sport.

During the eighteenth century English society underwent a civilising change. In England during the eighteenth century, apart from a growing state monopolization of violence there was also a process involving the refinement of manners and social standards. People were increasingly compelled to exercise greater, stricter and more continuous control, over their feelings, behaviour and violent impulses. Whenever the taboo concerning violence was violated, embarrassment and guilt feelings would emerge. An important aspect of this civilising process, with important implications for gender relations in sporting and non-sporting contexts, was the greater regulation of violence and aggression, that is, a more rigorous control over violence and more aggressive acts. At the same time people's propensity to take part in more violent acts or to derive pleasure from taking part and/or witnessing violent acts started to decrease. Violence started to be pushed behind the scenes. Such regulation of violence had its effects on the relations between men and women. As a result of an accumulation of controls and taboos on violence, individuals began slowly to be

Movimento, Porto Alegre, v. 20, n. 2, p. 757-773, abr.jun. de 2014. 
deprived of the right to use violence, especially in the public sphere. The belief that the use of violence was wrong became gradually deeply internalised. The emergence of feelings of guilt and shame became more frequent whenever the taboo regarding violence and aggression was violated. Men became gradually deprived of using one of their greatest advantages over women, that is, their physical force. Violence was, of course, not removed from social life but reduced. The external controls and self-control on physical violence led, as Dunning (1999, p. 228) notes, to "the increasing privatisation of such violence, to the pushing of it increasingly behind the scenes of social life, to its confinement increasingly to domestic social settings".

As a result of such social and self-control, the power chances of the relatively weaker groups began to increase. Moreover, the length of the interdependency chains increased since the middle Ages. These processes made the rulers and other powerful groups more dependent on those over whom they were dominant. This situation contributed to an increase of the power chances of those that were relatively weaker. It was in this context that women's power chances began to increase. Due to the existence of more strict rules regarding the use of physical force in general, men's power started to weaken while women's power chances began slowly to increase. The power balance between males and females started to change towards equalisation.

As some groups of women began to fight for their rights and started to have greater opportunities in terms of access to traditional male areas, men not only saw their masculinity being threatened but they also began to fear what Messner (1987 apud DUNNING, 1999) calls the feminisation of society. As a result, some men tried to keep areas such as sport as a privileged male space where traditional male values could be expressed. Since many sports have traditionally been defined in terms of strength, physical force, aggressiveness, that is, features traditionally associated with males, sport came to be seen as "an enclave for the legitimate expression of masculine aggression and for the development and expression

Movimento, Porto Alegre, v. 20, n. 2, p. 757-773, abr./jun. de 2014. 
of more traditional masculine habituses involving the use and display of physical prowess and power" (DUNNING; MAGUIRE, 1996, p. 308). Sport came to be seen as a privileged space for the inculcation, expression and perpetuation of male identities.

The increasing participation of women in sport in the twentieth century started to threaten the possibilities of male intimacy. Because women were challenging a male preserve, powerful ideologies questioning their femininity and claiming that physical damages could appear as a result of their involvement in sport, were put forward by some women as well as men. Scientific and technological developments later demonstrated that many of those ideas concerning women's participation in sport were no more than myths.

Women are, nowadays, involved in a great number of sports and are increasingly taking part in sports traditionally regarded as male appropriate sports. Such participation both reflects and constitutes a change in the power relations between men and women (COLWELL, 1999). The growing involvement of women in sport, although embodying a shift in the balance of power between males and females towards a greater equalisation, involves, according to Dunning (1999), two kinds of penalties for women. Firstly, women athletes face obstacles that are not experienced by male athletes. Secondly, while male athletes do not have to prove their masculinity, women athletes may see their femininity compromised, especially when they take part in combat/contact sports, that is, sports that have traditionally been regarded as less appropriate for females.

One of the distinctive features of figurational sociology is its concern to avoid dichotomies. This is of particular importance in relation to the analysis of sex and gender relations. There is a tendency amongst feminist theorists to analyse sex and gender differences in dichotomous terms, as if they were isolated and static entities, as if biological and social explanations of such differences could be analysed separately. To do that is to neglect the "changing, processual nature of sex/gender relations" (COLWELL, 1999, p.

Movimento, Porto Alegre, v. 20, n. 2, p. 757-773, abr.jun. de 2014. 
222). So, instead of thinking and talking in terms of sex and gender, it would be more adequate to speak of sex/gender. By doing that we can take into account the balance between "[...] nature and nurture, between biology, culture and society" (DUNNING, 1990 apud COLWELL, 1999, p. 223). This is of particular importance since human behaviour is not determined simply by either biology or culture. Humans depend on biology and also social-cultural learning for their survival. For Elias any "organism requires stimulation in order to function satisfactorily, particularly stimulation through the company of other human beings" (ELIAS, 1986 apud DUNNING, 1999, p. 15). These processes, then, must be analysed in relational terms since both are important in the shaping of human behaviour.

This same concern can be applied to gender and power relations. Since gender relations are power relations they are better understood as relational concepts, that is, as gender/power relations.

There is a tendency amongst feminists, and indeed sociologists generally, to treat men and women as homogeneous groups. In this regard figurational sociology has more to offer since it urges us to think in relational terms. Any study that intends to analyse the relations between femininity and females has to take into account masculinity and males. Moreover, if one wants to have a better understanding of sex/gender relations, the experiences of different kinds of men and also of different kinds of women have to take into account, for example, the different experiences of men and women of different class, age and ethnic groups, or different sexual orientations.

According to Colwell (1999), the works of feminists such as Scraton do present some strengths. For example, Scraton in her analysis of the social history and development of physical education in the United Kingdom has used a comparative and historical approach and by doing that she has contributed to a better understanding of how sex/gender relations in physical education have developed. But as Colwell (1999) points out, Stratton's analysis if often led

Movimento, Porto Alegre, v. 20, n. 2, p. 757-773, abr./jun. de 2014. 
by ideological underpinnings. For instance, Scraton argues that young women, through their involvement in physical education, should reject and challenge "competitive 'macho' values of the male sporting ethos [and should] gain access to the positive aspects of the sporting world" (apud COLWELL, 1999, p. 225). Scraton thus offer an ideological analysis in terms of what she considers to be positive and negative features. However, such evaluations in terms of good and bad, positive and negative, add nothing to our understanding of such phenomena. Through such assertions, we come to know more about Scraton believes to be the positive and negative features of sport, but this adds nothing to our understanding of relationships between those individuals and groups that take part in various sports. Ideological involvement of this kind is unhelpful and adds nothing of scientific value; it simply tells us about the author's own political and ideological preferences.

Evaluations and analyses led by ideological underpinnings can also be found in the work of other sports feminists. For example, in relation to abuse/exploitation in sporting settings most work in this area has been led by a feminist agenda and consequently most of the work that has been carried out ${ }^{1}$ has been based on the male perpetrator-female victim paradigm (HARTILL, 2005). But this kind of analysis presents major problems. Women and men tend to be presented as homogeneous groups, as if all women are exploited/abused and all men are perpetrators. There is a tendency to ignore the diversity of both female and male experiences. Some female athletes might be abused/exploited and some men might be abusers. However, men may also be exploited/abused and women may also be abusers. In this regard, Hartill (2005), after reviewing literature from social work and therapeutic disciplines, notes that there is growing evidence of abuse not just of girls and women, but

\footnotetext{
${ }^{1}$ Example of these studies are: FASTING; BRACKENRIDGE; WALSETH (2002). Coping with sexual harassment in sport: experiences of elite female athletes; VOLKWEIN et al. (2002). Sexual harassment of women in athletics vs academia; BRACKENRIDGE (1997). He owned me basically. Women's experiences of sexual abuse in sport; TOMLINSON; YOURGANCY (1997). Male coach/female athlete relations: gender and power relations in competitive sport; BRACKENRIDGE (1998). Healthy sport for healthy girls? The role of parents in preventing sexual abuse in sport: BRACKENRIDGE (2000). Harassment, sexual abuse and safety of the female athlete.
}

Movimento, Porto Alegre, v. 20, n. 2, p. 757-773, abr.jun. de 2014. 
also of boys and men, and there is also growing evidence of abuse of males by females.

This feminist ideologically driven analysis, by focusing exclusively on the male perpetrator-female victim paradigm, fails to acknowledge the fact "that some women impose their values on other women, and that women have their own sources of power in relation to one another and to men" (COLWELL, 1999, p. 222). That is, both males and females may be abusers, or may be abused.

This exclusive focus on the male perpetrator-female victim paradigm indicates the degree to what such studies are based more on ideological assumptions than on empirical evidence and it is this ideological commitment which has led them to ignore the growing evidence of male abuse and female abusers. Thus again, most of the studies carried out in this area tell us more about the researcher's' ideologies, beliefs and concerns than about what actually happens in sporting contexts. According to Mendel (1995 apud HARTILL, 2005), because of popular ideas about what it is to be a male and ideas about femininity, it is difficult to recognise males as victims and females as perpetrators. Because many sports have customarily been defined in terms of features traditionally associated with males, sport came to be seen as a privileged space for the construction, expression and perpetuation of male identities. As a consequence, for many of those researching in this area, and also for many males, it is difficult to acknowledge the existence of abuse and exploitation of males by females in sporting settings, since to acknowledge this would be regarded by many as a threat to masculinity.

Confronting and acknowledging sexual abuse poses a major threat to male's sense of masculinity. A male victim may assume that he is 'less of a man' due to his inability to protect himself and to his experience in a helpless, victimized role. (MENDEL, 1995 apud HARTILL, 2005, p. 296).

It is also due to beliefs about femininity that female perpetration tends to be under-recognised. For Mendel (1995 apud HARTILL, 2005, p. 299) these beliefs include:

Movimento, Porto Alegre, v. 20, n. 2, p. 757-773, abr.jun. de 2014. 
The self-fulfilling assumption that female perpetration is rare; denial of female sexuality and aggression; belief that sexual interaction with older females is benign or positive; greater leeway given to females than males in their physical interactions with children; politically based avoidance of acknowledgment of female perpetration.

Most of the studies on abuse and exploitation in sporting contexts thus tell us much more about researchers' ideologies and values than about what actually happens. From a figurational perspective, this kind of analyses adds nothing to our understanding of what really happens in sporting contexts in terms of abuse and exploitation.

The above examples can be seen as a perfect illustration of Elias's ideas about involvement and detachment. If the analysis with which we are presented tells us more about the researchers' beliefs and values than about the ostensible object of study, then this is a clear indication that the researchers are so highly involved that their analysis is led by their beliefs and concerns. In other words, because they do not control their involvement, their extra-scientific ideas interfere in their analysis. Because of their involvement their theoretical approach tends to be biased. And if their theoretical approach is biased, their analyses will also be biased. And when the analysis is biased, the quality of the policy recommendations will also be adversely affected. This is what frequently happens with feminist sociologists. The tendency to be highly involved and to be led by ideological assumptions can be seen as a central weakness of feminist approaches to sport. In this regard a figurational approach, it is suggested, has more to offer. For figurational sociologists researchers should try to put aside their personal beliefs and concerns since these can bias the analysis and thus obscure the understandings of the issue under study. Researchers should seek to control their involvement and seek to offer a relatively detached analysis, that is, one which is relatively free from extra-scientific values and concerns.

Movimento, Porto Alegre, v. 20, n. 2, p. 757-773, abr.jun. de 2014. 
The ideological assumptions which underpin much feminist writing is thus rejected by figurationalists. Moreover, the differences between these approaches make it difficult to combine them when studying, for example, sport and sex/gender relations. The work of Maguire and Mansfield (1998) is a clear example of the problems involved in any attempt to combine these different perspectives.

Although informed by what the authors describe as a "feminist figurational" approach, Maguire and Mansfield's work reveals the difficulties involved in any attempt to combine these approaches. For example, although they state that in their study they would treat women as a heterogeneous group they fail to do so and there are numerous instances where women are treated as $\mathrm{s}$ single, undifferentiated group. For example: "It is the pursuit of the social body that is a negative strategy for women" (MAGUIRE; MANSFIELD, 1998, p. 135).

Here they appear to be treating women as a homogeneous group, as if for all women the pursuit of the social body is a negative strategy. For some, of course, it may be a negative strategy but for others it may serve them well in what they perceive to be their best interests.

Elsewhere, Maguire and Mansfield argue: "Women are under pressure from societal images reinforced within the 'exercisebody beautiful complex' to stay young, slim and healthy. They do aerobics in response to that pressure" (MAGUIRE; MANSFIELD, 1998, p. 125).

Here again the authors treat women as a homogenous group. Not all women do aerobics in an attempt to respond to the pressure they are submitted. For some this may be the reason but others might do aerobics for the exercise and for the pleasure it gives.

The authors, besides treating women as a homogenous group, also make value judgments throughout their work. For example, they refer in relation to the women they studied: "These women are ...oppressed in their pursuit of the social body" (MAGUIRE; MANSFIELD, 1998, p. 117).

Movimento, Porto Alegre, v. 20, n. 2, p. 757-773, abr./jun. de 2014. 
And they also uncritically accept Markula's judgement that:

Aspiring to tighten, tone, and reduce the thighs, hips, bottom, stomach and breasts, they adhere to a distorted notion of femininity that is defined by dominant social ideologies. (MARKULA, 1995 apud MAGUIRE; MANSFIELD, 1998, p. 125)

In both quotations it is possible to identify the following value judgments: women are oppressed and women are adhering to a distorted notion of femininity. These kind of claims, as Colwell (1999, p. 234) notes, "blinds us to the fact that these notions of femininity are unlikely to be perceived as 'distorted' by all women". Some women might indeed perceive these notions as distorted, but others may not agree and may find that adherence to these ideas serves them well. Moreover, it is clear that not all women feel oppressed in their pursuit of the social body. These claims therefore raise the following questions: is it the women in Maguire and Mansfield's work that perceive these notions of femininity as distorted, or is this the authors' own value judgement? Is it the women in the study who feel they are oppressed in their pursuit of the social body or it is what the authors think? Again, these kinds of statements tell us more about the authors' views and beliefs than about the women they studied; in a word, they are ideologies.

Colwell (1999) argues that, in Maguire and Mansfield's work, it is possible to identify another aspect that shows the difficulty of combining feminist and figurational approaches. In their work, Maguire and Mansfield (1998, p. 124), argue "that women consciously shape their bodies according to the societal norms of femininity". The main problem here relates to their notion of "societal norms of femininity". In society there is not just a single set of norms of femininity. In society people "follow different norms in different spheres of their lives ... conduct which may be normal in one sphere may be deviant in another" (ELIAS; DUNNING, 1986, p. 101).

Movimento, Porto Alegre, v. 20, n. 2, p. 757-773, abr.jun. de 2014. 


\section{FINAL REMARKS: THE POSSIBILITY FOR A SYNTHESIS}

The examples presented above show the difficulties that arise whenever it is attempted to combine feminist and figurational approaches. As Colwell (1999) notes, most of the problems tend to centre around the question of values. For many feminists it would seem impossible to offer, and many would find it difficult to accept, any kind of analysis without evaluation. However, from a figurational standpoint, to allow the interference of extra-scientific views and ideologies in any kind of research (something quite common in feminist approaches) is unacceptable. So, as Colwell (1999, p. 236) notes, it seems untenable to offer a "feminist-figurationlist" approach because the moral/political evaluation which is central to feminist approaches is strongly rejected by figurationalists. Therefore she suggests that instead of a feminist figurational approach, what we can be is a "feminist informed figurational sociologist" (COLWELL, 1999, p. 236). However, this position, as Mansfield (2008), asserts is based on the claim that evaluation is a central feature of feminist perspectives and something highly rejected by figurationalists. To sustain such position is to suggest that feminists and figurationalists are placed "at opposite extremes of an evaluation/non-evaluation dichotomy" (MANSFIELD, 2008, p. 104). In other words, Colwell is making an evaluation of these two kinds of perspectives and placing them totally in opposition. This can be seen as misinterpretation of Elias theory of involvement and detachment. Elias (1978), never expressed a strong rejection for evaluation or a necessity for nonevaluation. What he has always claimed was that sociologists in their researches:

[...] should strive to free themselves from the idea that there might be any necessary correspondence between the social context under investigation, and their own social beliefs, their wishes and hopes, their moral predilections or their conceptions of what is just and humane. (ELIAS, 1978, p. 153).

Elias always encouraged sociologists to research areas of their own interests, to have an insider knowledge (although this does not

Movimento, Porto Alegre, v. 20, n. 2, p. 757-773, abr./jun. de 2014. 
mean to privilege such kind of knowledge). Since he did not consider involvement as something completely bad. According to him, certain forms of involvement could even facilitate the research process. In fact, in order to have a better understanding of how human groups work, a person has to know from the inside how different individuals experience their own group as well as other groups. This means that without an active participation and involvement it becomes more difficult for a person to understand how human groups work. However, researchers should not be highly emotionally involved, since a strong emotional involvement might distort the understanding of the process. One needs to be involved in a scientific sense, that is, one has to try to control one's emotional involvement and seek to attain the highest level of detachment -a detour via detachment as it is called by Elias. That is, although involved, researchers should try to put aside their personal convictions and concerns in order to be able to study the relevant processes in a more detached manner. Only a relatively detached analysis will result in a more realistic or reality-congruent analysis of the processes researchers are seeking to understand, since it is likely to be less "subject to the distorting and biasing effects of ideological preoccupations" (MURPHY, 1994, p. 154). Such involvement, or in other words, such insider knowledge advocated by Elias does not contradict feminist principles of research. Mansfield (2008) quoting Reinharz (1992), refers that "the most satisfactory position for feminist researchers is one that acknowledges the researcher's position right up front, and that does not think of objectivity and subjectivity as warring with each other, but rather serving each other" (p. 107). In this regard Mansfield (2008, p. 105) introduces the notion of involved-detachment. By this she means:

[...] a balance signalling a feminist passion or motivation to investigate gender relations in sport from an inside perspective; a requirement to be involved, but recognizing and examining the feminist assumptions of the research endeavour and working towards an appropriate degree of detachment from those feminist values in the advancement of knowledge about gender, sport and sport related activities.

Movimento, Porto Alegre, v. 20, n. 2, p. 757-773, abr.jun. de 2014. 
If a feminist researcher works with this idea of involveddetachment, more object adequate explanations will be produced. In this sense, it is possible to be a feminist and also a figurational sociologist. However, such idea requires more theoretical and empirical evidence.

Uma análise do debate feminismo versus sociologia
configuracional no estudo do gênero e do desporto
Resumo: Este artigo fornece uma análise do debate que
tem sido realizado sobre a possibilidade de combinar as
perspectivas configuracional e feminista no estudo do gênero
e do esporte. Nesta análise, algumas das diferenças entre
as abordagens feministas e configuracional são brevemente
mencionadas e as ideias de Elias sobre o envolvimento
e distanciamento são apresentados como uma solução
possível para combinar as abordagens.
Palavras-chave: sociologia, feminismo, identidade de
gênero, esportes.

Un análisis del debate feminista frente a la sociología configuracional en el estudio de género y el deporte

Resumen: En este artículo se presenta un análisis del debate que se ha llevado a cabo sobre la posibilidad de combinar perspectivas configuracionales y feministas en el estudio del género y el deporte. En este análisis, algunas de las diferencias entre los enfoques feministas y configuracional se mencionan brevemente y las ideas de Elias sobre el compromiso y distanciamiento, se presentan como una posible solución para combinar los enfoques.

Palabras-clave: sociología, feminismo, identidad de género, deportes

\section{REFERENCES}

BIRRELL, S. Feminist theories for sport. In: COAKLEY, J.; DUNNING, E. (Eds.). Handbook of sports studies. London: Thousand Oaks, New Delhi: Sage, 2000. p. 61-76.

BRACKENRIDGE, C.H. "He owned me basically": women's experience of sexual abuse in sport. International Review for the Sociology of Sport, Los Angels, London, New Delhi, Singapore, Washington, v. 3, n. 2, p. 115-30, 1997.

BRACKENRIDGE, C.H.. Healthy sport for healthy girls? The role of parents in

Movimento, Porto Alegre, v. 20, n. 2, p. 757-773, abr.jun. de 2014. 
preventing sexual abuse in sport. Sport, Education and Society, London, v. 3, n. 2, p. 59-78, 1998.

BRACKENRIDGE, C.H. Harassment, sexual abuse and safety of the female athlete. Clinics in Sport Medicine, Philadelphia, New York, v. 19, n. 2, p. 187-198, 2000.

CAUDWELL, J. Women's football in the United Kingdom: theorizing gender and unpacking the butch lesbian image. Journal of Sport \& Social Issues, London, v. 23, n.4, p. 390-402, 1999.

COLWELL, S. Feminisms and figurational sociology: contributions to understandings of sports, physical education and sex/gender. European Physical Education Review, London, v. 5, n. 3, p. 220-240, 1999.

DUNNING, E. Figurational sociology and the sociology of sport: some concluding remarks. In: DUNNING, E.; ROJEK, C. (Eds.), Sport and leisure in the civilizing process: critique and counter-critique. London: Macmillan, 1992a. p. 221-284.

DUNNING, E. O desporto como uma área masculina reservada: notas sobre os fundamentos sociais na identidade masculina e as suas transformações. In: ELIAS, N.; DUNNING. E. (Eds.). A busca da excitação. Lisboa: Difel, 1992b. p. 389-412.

DUNNING, E. Sport matters. London: Routledge, 1999.

DUNNING, E.; MAGUIRE, J. Process-sociological notes on sport, gender relations and violence control. International Review for Sociology of Sport, Los Angels, London, New Delhi, Singapore, Washington, v. 31, n. 3, p. 296-321, 1996.

DUNNING, E.; SHEARD, K. Barbarians, gentlemen and players. London: Preface, 1979.

ELIAS, N. What is sociology? London: Hutchinson, 1978.

ELIAS, N.; DUNNING, E. Leisure in the spare-time spectrum. In: ELIAS, N.; DUNNING, E. (Eds.). Oxford: Blackwell, 1986.

FASTING, K.; BRACKENRIDGE, C.H.; WALSETH, K. Coping with sexual harassment in sport: experiences of elite female athletes, The Journal of Sexual Aggression, Oxford, v. 8, n. 2, p. 16-36, 2002.

HARGREAVES, J. Sporting females: critical issues in the history and sociology of womens' sports. London: Routledge, 1994.

HARTILL, M. Sport and the sexually abused male child. Sport Education and Society, London, v. 10, n. 3, p. 287-304, 2005.

LISTON, K. Revisiting the feminist-figurational sociology exchange. Sport in society, London, v. 10, n. 4, p. 623-645, 2007.

MAGUIRE, J.; MANSFIELD, L. "No-body's perfect": women, aerobics, and the body beautiful. Sociology of Sport Journal, Edmonton, Canada, v. 15, n. 2, p. 109-137, 1998.

Movimento, Porto Alegre, v. 20, n. 2, p. 757-773, abr.jun. de 2014. 
MANSFIELD, L. Reconsidering feminisms and the work of Norbert Elias for understanding gender, sport and sport-related activities. European Physical Education Review, London, v. 14, n. 1, p. 93-121, 2008.

MARKULA, P. Firm but shapely, fit but sexy, strong but thin: the postmodern aerobicizing female bodies. / Ferme mais bien faite, en forme mais sexy, forte mais fine: image du corps feminin post-moderne en danse aerobique. Sociology of Sport Journal, Edmonton, Canada, v. 12, n. 4, p. 424-453, 1995.

MARKULA, P. The technologies of the self: sport, feminism, and Foucault. Sociology of Sport Journal, Edmonton, Canada, v. 20, n. 2, p. 87-107, 2003.

MENDEL, M. P. The male survivor: the impact of sexual abuse. London: Sage, 1995.

MESSNER, M. The life of a man's seasons: male identity in the life course of the jock. In: KIMMEL, M: S. (Ed.). Changing men. London: Sage, 1987. p. 53-67.

MURPHY, P. The roles of values in the sociology of sport. Introduction to the Sociology of Sport - Module 1 Unit 3. Leicester: University of Leicester, 1994. p. 147-156.

REINHARZ, S. Feminist methods in social research. Oxford: University Press, 1992.

SCRATON, S.; FLINTOFF, A. Sport feminism: the contribution of feminist thought to our understandings of gender and sport. In: SCRATON, S.; FLINTOFF, A. (Eds.). Gender and sport: a reader. London: Routledge, 2002a. p. 30-46.

SCRATON, S.; FLINTOFF, A. Gender and sport: a reader. London: Routledge, 2002b.

THEBERGE, N. "No fear comes". Youth \& Society, London, v. 34, n. 4, p. 497-516, 2003.

TOMLINSON, A.; YORGANCI, I. Male coach/female athlete relations: gender and

power relations in competitive sport. Journal of Sport and Social Issues, London, v. 21, n. 2, p. 134-55, 1997.

VOLKWEIN, K., SCHNELL, F., DEVLIN, S., MITCHELL, M. ; SUTERA, J. Sexual harassment of women in athletics vs. academia, The Journal of Sexual Aggression, Oxford, v. 8, n. 2, p. 16-36, 2002.

WADDINGTON, I.; MALCOLM, D.; COBB, J. Gender stereotyping and physical education. European Physical Education Review, London, v. 4, n. 1, p. 34-46, 1998. 
An analysis of the feminist-figurational ...

Endereco para correspondencia

Av. Carlos Oliveira Campos

Castelo da Maia

4475-690 Avioso S. Pedro

Maia

Portugal

Recebido em: 01.10.2013

Aprovado em: 14.02.2014

Movimento, Porto Alegre, v. 20, n. 2, p. 757-773, abr.jun. de 2014. 